\title{
CARBON STOCK ESTIMATION USING REMOTE SENSING DATA AND FIELD MEASUREMENT IN HALOXYLON AMMODENDRON DOMINANT WINTER COLD DESERT REGION OF MONGOLIA
}

\author{
Bayartungalag Batsaikhan ${ }^{1,2}$, , Ochirkhuyag Lkhamjav ${ }^{2}$, Gantungalag Batsaikhan ${ }^{3}$, Nandinbayar Batsaikhan ${ }^{2,3}$, Bayanmunkh \\ Norovsuren $^{2}$ \\ ${ }^{1}$ Institute of Geography and Geo-ecology, Mongolian Academy of Sciences, Ulaanbaatar-15170, Mongolia - \\ bayartungalag_b@mas.ac.mn \\ ${ }^{2}$ Mongolian Geo-spatial Association, Ulaanbaatar-15141, Mongolia, ochirkhuyag@ geomedeelel.mn \\ ${ }^{3}$ Mongolian University of Life Sciences, Zaisan-17024, Ulaanbaatar, Mongolia
}

Commission III, TC III/10

KEY WORDS: Carbon stock, Haloxylon ammodendron, Saxaul vegetation, Winter cold desert, Western Mongolia, Gobi-Altai

\begin{abstract}
:
The UN-REDD Mongolia National Programme has studied about forest carbon emissions, and enhance and sustainably manage its carbon stocks, through the implementation of REDD+ activities since 2011. However, the current assessments seem to remain uncertain, the study for estimating carbon storage based on field survey are still rare. Because the Haloxylon ammodendron, where Gobi desert ecosystems are covering large areas, it is necessary to develop a modelling approach applying remote sensing. The study area is locating in Gobi-Altai province, Trans-Altai area as the south-western part of Mongolia. A total of 32 plots were established on eighth different land cover types to represent the range of variability. The study was used high spatial resolution imagery of Pleiades- 1 and both of active and passive data from Sentinel-1 and Sentinel-2. The growing height in 32 plots is ranging from 20 to $460 \mathrm{~cm}$ with between 0.002 and $544.9 \mathrm{~cm}^{2}$ for basal area and between 526.5 and $166106.0 \mathrm{~cm}^{2}$ for canopy area, respectively. Shrub density is very high in plot $4(\mathrm{n}=135)$ and plot $5(\mathrm{n}=117)$ with low above-ground biomass $12 \mathrm{~kg}$ and $10.9 \mathrm{~kg}$. The backscatter $(\mathrm{dB})$ values of vegetated area and non-vegetated were comparable, -27.86 and -17.36 in VH polarisation and -22.72 and -10.61 in VV polarisation, respectively. Model-M1 was best demonstrated when a combination of vegetation coverage area was used as Pleiades-1 and Sentinel-2 derived vegetation cover data. For model-M9, the results were comparable to model-M1 but with lower the coefficient of determination. In this work, NDVI and MSAVI appear as a good indicator of biomass mainly because it does not saturate in sparse shrubs and is more sensitive to canopy parameters.
\end{abstract}

\section{INTRODUCTION}

The Gobi desert ecosystem is covering about 38 percent of total land area in Southern Mongolia is the continuous part of temperate deserts, which is rich by species of the flora and fauna important for Central Asian desert ecosystem. In the Ecoregion with an extreme dry and semiarid continental climate, with strong, long-lasting frost in winter and extremely hot summer with very low annual precipitation of less than 150 $\mathrm{mm}$.

The last decades, climate change has been materializing through the extreme climatic conditions are critically affected to desertification, biodiversity loses, poverty of nomadic herder's livelihood, loses of livestock number, decreases of water sources, land and vegetation degradation. Especially the climate functioning is relatively higher on major species of plant which is dominated by shrubs and semi-shrubs of Haloxylon ammodendron in the vast expanse of the Gobi-Desert area across the Southern Mongolia (Peter D Gunin et al., 2013). There are also human activities have resulted in the degradation of vegetation with harvesting by the herders for the source of fuel and foraging of the Bactrian camel. Among the drivers of both climate and human, deforestation and degradation processes have been increasing significant impact on carbon cycling.

The Haloxylon ammodendron grows in all ecoregions of the Gobi Desert which is harsh habitats such as moving or fixed sands, saline depressions, dry canyons, clay and rock sub montane planes, rocky hill and mountain slopes and tertiary bed lands. An area within the desert approximately $1650 \mathrm{~km}$ wide and $360 \mathrm{~km}$ in diameter from north to south, the area is 4.5 million ha actually under closed cover is about 2 million ha (Yamamura et al., 2013): they represent the largest carbon stock in the Southern Mongolia and Central Asia. The standing stock of Haloxylon in southern Mongolia is approximately 1404.1 (per $\mathrm{m}^{3}$ ) Yamamura et al., 2013. Most of Haloxylon ammodendron biomass as carbon stock in winter-cold deserts zones of central Asia have been extensively studied, in Kazakhstan, Uzbekistan, Turkmenistan, Northern China (Buras et al., 2012; Thevs et al., 2013; Li et al., 2015; Chen, Y., et al. (2016); Eisfelder et al., 2017 and Zhagloskaya et al., 2017) and Southern Mongolia have been studied in some detail by Zhang et al., 2016. Previous detailed research on the vegetation of southern deserts was conducted by Rachkovskaya (1993) and Rachkovskaja \& Volkova (1977), recent publications von Wehrden et al., 2006 and Von Wehrden et al., 2007 suggest that the present result is not detailed enough with respect to the southern Mongolian deserts, which have rarely been studied for estimation of biomass as carbon stock. Mongolian National inventory including the UN-REDD Mongolia National Programme has studied about carbon emissions, and enhance and sustainably manage its carbon stocks, through the implementation of REDD+ activities since 2011. However, the current assessments seem to remain uncertain, the study for

\footnotetext{
* Corresponding author
} 
estimating carbon storage based on field survey are still rare. Because the Haloxylon ammodendron, where Gobi desert ecosystems are covering large areas, it is necessary to develop a modelling approach applying remote sensing. The remote sensing and geographical information systems (GIS) have been well applied in the estimation of biomass carbon in central Asia especially in northern China by Chen, Y., et al. (2016); Ma, Q., et al. (2017); Eisfelder, C., et al. (2017); Shao, Z. and L. Zhang (2016) and Jia, W., et al. (2016).

In this study we were evaluated carbon stock using multispectral data combined with radar image based on the field survey data, relations between remote sensing data and the ground biomass parameters were established to use the continuous spatial-temporal remote sensing data to estimate biomass parameters at spatial scales. With this background we propose (1) to provide biomass and carbon stock estimation of vegetation as Haloxylon ammodendron in western local GobiDesert region of Mongolia based on the field measurements and remote sensing data; (2) to quantify the spatial distribution of regional vegetation biomass and carbon stock, and (3) to develop a modelling approach with the relative contribution of each field and remote sensing data. This modelling approach will allow determining carbon stock of vegetation in other Gobi-Desert regions of Mongolia which focused on determining driving forces.

\section{MATERIAL AND METHODS}

\subsection{Study area}

The study area is locating in Trans-Altai as south western part of Mongolia occupying southern parts of approximately $150 \mathrm{~km}$ from the centre of Erdene soum, Gobi-Altai province $\left(44^{\circ} 07^{\prime}\right.$ $44^{\circ} 98^{\prime} \mathrm{N}$ and $96^{\circ} 98^{\prime}-98^{\circ} 26^{\prime} \mathrm{E}$ ) (Fig. 1). The study and sampling sites were situated in a valley enclosed by tall mountains which is elevations range from $1,000 \mathrm{~m}$ a.s.l. near the north-western corner of the site to $2,840 \mathrm{~m}$ a.s.l. along the Mongol-Altai Mountains. Regarding western Gobi desert ecosystems, most of the area belongs to the real Gobi desert zone; the northern parts have mountain semi-desert, and southern parts falls into the extra-arid desert zone characteristics. The climate is a continental semiarid with a harsh, long cold winter and short, hot summer, low precipitation, and large temperature fluctuation between day and night and between summer and winter the average monthly temperature is $-13{ }^{\circ} \mathrm{C}$ in winter and $25{ }^{\circ} \mathrm{C}$ in summer, respectively, and average rainfall amount is $59 \mathrm{~mm}$ with most precipitation falling during summer. A sum of the annual precipitation is very low and ranges between 39-65 $\mathrm{mm}$ per year, however, in lowland, the precipitation amount is little higher raising to $50-55 \mathrm{~mm}$, in mountains, it is $55-65 \mathrm{~mm}$. In seasonal distribution, $77.3 \%$ of total precipitation falls in the warm period of the year and the rest in the winter season. An extraordinary arid environment is widely dominated by Haloxylon ammodendron with the participation of Anabasis, Reaumuria and Sympegma on a dry riverbed, sandy hill and dark-coloured rocky outcrop deserts. The dominant species in real deserts are Halloxylon ammodendron, Zygophyllum xanthoxylon, Nitraria spp. In extra arid deserts along dry streambed Ephedra przewalskii, Anabasis brevifolia and Haloxylon ammodendron are widespread. The soil and vegetation cover of this region highly dependent from climatic conditions, therefore mainly low height, less nutrition, salt and heat adapted grass and shrub species growing. In deserts different saltwort (Reumuria soongorica, Anabasis brevifolia, Salsolaa spp. etc.), Achnatherum spp., Berberis sibirica, Amygdalus mongolica, Caragana spp., Haloxylon ammodendron are dominating, however along rivers and oases
Populus diversifolia, Elaeagnus moorcroftii, Ulmus pumila, Tamarix spp. trees are common. The deserts famous by its rare, medicinal and useful plants, such as Nitraria spp., Cistanche deserticola, Allium bidentatum, Ajania spp., Ephedra spp., Artemisia rutifolia, Artemisia spp., Oxytropsis spp. are sparsely distributed.

The Haloxylon ammodendron (Fig 2) has a succulent root system that reaches out extensively for water, both laterally and deeply, with more success in sandy than in heavily textured soils. In sandy soil developed much deeper root systems, larger root surface areas. Some examined the root system of Haloxylon on dune covered sand are spreading horizontally $50-100 \mathrm{~cm}$ below the surface due to the high salinity and salt incrustation of the spots the main root does not reach deep soil layers. We found some small height of Haloxylon without any species accompany which grow along drainage lines on sealed by a dark stone net with harsh site conditions. While better Conditions for plant growth Haloxylon stands with other species which grow higher than 1 to 3 meter within oasis consist of desert plains, low meadows and marshlands.

Distributions and resources of Haloxylon have decreased by illegal harvesting of local and outside communities for household and commercial uses. The Gobi-Desert area is utilized for winter pastures. Last decided, numbers of wintering settlements and herding families have increased in the area from the neighbour province. Reason of pastureland degradation has occurred in particular in the Bayan-Undur soum of Bayankhongor after hot summers with low precipitation and cold winters. Several species, including herding families with a number of the Bactrian camels, have been extirpated from the southern gobi as a result of anthropogenic activity.

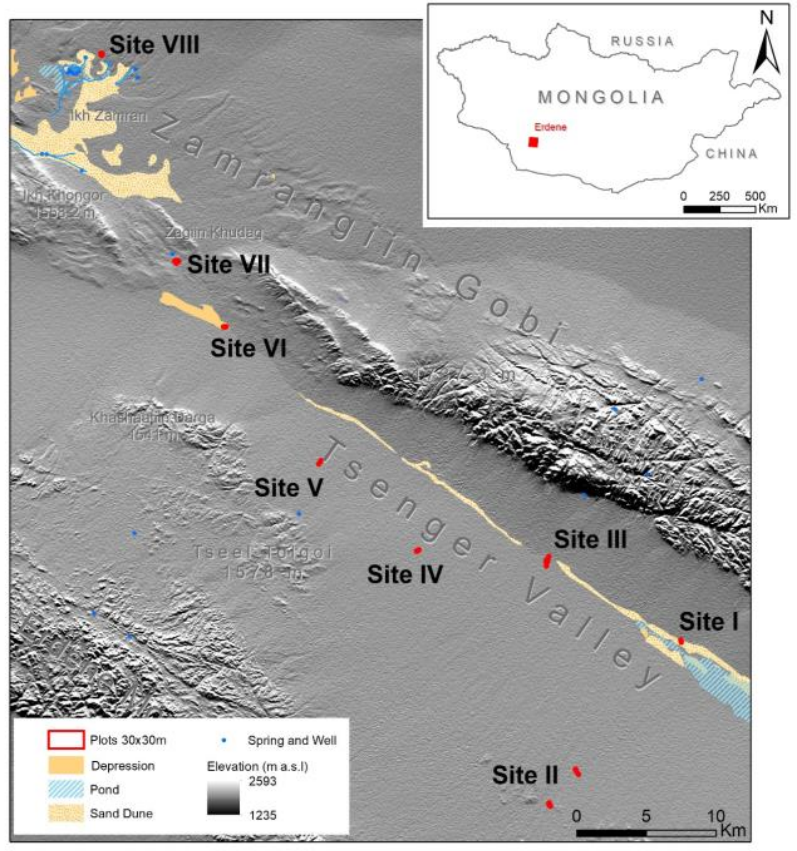

Figure 1. The study site in Gobi-Altai province, Trans-Altai as south western part of Mongolia.

\subsection{Field description and data sampling}

A total of 32 plots were established on eighth different land cover types to represent the range of variability which is oasis, sandy hill \& dunes, dark-coloured rocky, dry former river banks and depressions as those are the most frequent type of varieties 
within Mongolia Gobi desert region (Table 1). All field measurements and sampled data were collected between 22 March and 4 April 2018 with nice weather without rain, snow and wind. At each site, least two to five plots were arranged cover of possible shrub density from very low density to the highest density depending on visible features on the vegetation from low growing height to high growing height.

2 and 5 plots are situated for each site I and VII respectively, represents a growing condition of vegetation on fixed sand dunes and sandy hill. 6 plots for site II, 2 plots for site IV and 2 plots for site $\mathrm{V}$ have been represented dominated shrub features from low growing height to medium-low growing height on former river banks mixed with fine sand covered by dark coloured small rocky. Site III is located near to rocky hill with 7 plots on moving sand mixed with fine sand covered by dark coloured small rocky. 3 plots were investigated in site VI and represent the growing condition of shrubs on dry bed land of saline depression, while site VIII with 5 plots were disturbed within oasis and represents good environmental conditions for the growth of high height shrubs due to the comparably good water supply (Table 1).

\begin{tabular}{|c|c|c|c|c|}
\hline Sites & Plot No & Northing & Easting & $\begin{array}{l}\text { Landscape } \\
\text { type }\end{array}$ \\
\hline \multirow{2}{*}{ I } & 1 & $97^{\circ} 52^{\prime} 29.11^{\prime \prime}-97^{\circ} 52^{\prime} 30.47^{\prime \prime}$ & $44^{\circ} 26^{\prime} 38.82^{\prime \prime}-44^{\circ} 26^{\prime} 39.77^{\prime \prime}$ & \multirow{2}{*}{ Sand dune } \\
\hline & 2 & $97^{\circ} 52^{\prime} 31.28^{\prime \prime}-97^{\circ} 52^{\prime} 32.66^{\prime \prime}$ & $44^{\circ} 26^{\prime} 33.07^{\prime \prime}-44^{\circ} 26^{\prime} 34.03^{\prime \prime}$ & \\
\hline \multirow{6}{*}{ II } & 3 & $97^{\circ} 47^{\prime} 2.66^{\prime \prime}-97^{\circ} 47^{\prime} 4.04^{\prime \prime}$ & $44^{\circ} 21^{\prime} 21.88^{\prime \prime}-44^{\circ} 21^{\prime} 22.84^{\prime \prime}$ & \multirow{6}{*}{ Desert plain } \\
\hline & 4 & $97^{\circ} 46{ }^{\prime} 59.79^{\prime \prime}-97^{\circ} 47^{\prime} 1.18^{\prime \prime}$ & $44^{\circ} 21^{\prime} 25.64^{\prime \prime}-44^{\circ} 21^{\prime} 26.60^{\prime \prime}$ & \\
\hline & 5 & $97^{\circ} 46^{\prime} 53.61^{\prime \prime}-97^{\circ} 46^{\prime} 54.93^{\prime \prime}$ & $44^{\circ} 21^{\prime} 33.69^{\prime \prime}-44^{\circ} 21^{\prime} 34.65^{\prime \prime}$ & \\
\hline & 6 & $97^{\circ} 45^{\prime} 29.86^{\prime \prime}-97^{\circ} 45^{\prime} 31.25^{\prime \prime}$ & $44^{\circ} 20^{\prime} 9.84^{\prime \prime}-44^{\circ} 20^{\prime} 10.81^{\prime \prime}$ & \\
\hline & 7 & $97^{\circ} 45^{\prime} 28.97^{\prime \prime}-97^{\circ} 45^{\prime} 30.36^{\prime \prime}$ & $44^{\circ} 20^{\prime} 13.81^{\prime \prime}-44^{\circ} 20^{\prime} 14.78^{\prime \prime}$ & \\
\hline & 8 & $97^{\circ} 45^{\prime} 34.15^{\prime \prime}-97^{\circ} 45^{\prime} 35.54^{\prime \prime}$ & $44^{\circ} 20^{\prime} 7.17^{\prime \prime}-44^{\circ} 20^{\prime} 8.13^{\prime \prime}$ & \\
\hline \multirow{7}{*}{ III } & 9 & $97^{\circ} 45^{\prime} 9.85^{\prime \prime}-97^{\circ} 45^{\prime} 11.24^{\prime \prime}$ & $44^{\circ} 29^{\prime} 33.16^{\prime \prime}-44^{\circ} 29^{\prime} 34.13^{\prime \prime}$ & \multirow{7}{*}{$\begin{array}{l}\text { Moving } \\
\text { sand }\end{array}$} \\
\hline & 10 & $97^{\circ} 45^{\prime} 11.51^{\prime \prime}-97^{\circ} 45^{\prime} 12.89^{\prime \prime}$ & $44^{\circ} 29^{\prime} 35.78^{\prime \prime}-44^{\circ} 29^{\prime} 36.72^{\prime \prime}$ & \\
\hline & 11 & $97^{\circ} 45^{\prime} 7.90^{\prime \prime}-97^{\circ} 45^{\prime} 9.27^{\prime \prime}$ & $44^{\circ} 29^{\prime} 38.21^{\prime \prime}-44^{\circ} 29^{\prime} 39.15^{\prime \prime}$ & \\
\hline & 12 & $97^{\circ} 45^{\prime} 9.47^{\prime \prime}-97^{\circ} 45^{\prime} 10.86^{\prime \prime}$ & $44^{\circ} 29^{\prime} 41.26^{\prime \prime}-44^{\circ} 29^{\prime} 42.22^{\prime \prime}$ & \\
\hline & 13 & $97^{\circ} 45^{\prime} 13.62^{\prime \prime}-97^{\circ} 45^{\prime} 15.00^{\prime \prime}$ & $44^{\circ} 29^{\prime} 41.95^{\prime \prime}-44^{\circ} 29^{\prime} 42.9^{\prime \prime}$ & \\
\hline & 14 & $97^{\circ} 45^{\prime} 16.01^{\prime \prime}-97^{\circ} 45^{\prime} 17.40^{\prime \prime}$ & $44^{\circ} 29^{\prime} 48.61^{\prime \prime}-44^{\circ} 29^{\prime} 49.58^{\prime \prime}$ & \\
\hline & 15 & $97^{\circ} 45^{\prime} 8.88^{\prime \prime}-97^{\circ} 45^{\prime} 10.27^{\prime \prime}$ & $44^{\circ} 29^{\prime} 26.31^{\prime \prime}-44^{\circ} 29^{\prime} 27.27^{\prime \prime}$ & \\
\hline \multirow{2}{*}{ IV } & 31 & $97^{\circ} 38^{\prime} 6.61^{\prime \prime}-97^{\circ} 38^{\prime} 8.00^{\prime \prime}$ & $44^{\circ} 29^{\prime} 56.20^{\prime \prime}-44^{\circ} 29^{\prime} 57.17^{\prime \prime}$ & \multirow{4}{*}{$\begin{array}{l}\text { Dry } \\
\text { streambed }\end{array}$} \\
\hline & 32 & $97^{\circ} 38^{\prime} 13.44^{\prime \prime}-97^{\circ} 38^{\prime} 14.83^{\prime \prime}$ & $44^{\circ} 29^{\prime} 59.07^{\prime \prime}-44^{\circ} 30^{\prime} 0.02^{\prime \prime}$ & \\
\hline \multirow{2}{*}{$\mathrm{V}$} & 29 & $97^{\circ} 32^{\prime} 43.40^{\prime \prime}-97^{\circ} 32^{\prime} 44.77^{\prime \prime}$ & $44^{\circ} 33^{\prime} 15.80^{\prime \prime}-44^{\circ} 33^{\prime} 16.78^{\prime \prime}$ & \\
\hline & 30 & $97^{\circ} 32^{\prime} 50.46^{\prime \prime}-97^{\circ} 32^{\prime} 51.85^{\prime \prime}$ & $44^{\circ} 33^{\prime} 23.20^{\prime \prime}-44^{\circ} 33^{\prime} 24.17^{\prime \prime}$ & \\
\hline \multirow{3}{*}{ VI } & 16 & $97^{\circ} 27^{\prime} 32.91^{\prime \prime}-97^{\circ} 27^{\prime} 34.30^{\prime \prime}$ & $44^{\circ} 38^{\prime} 31.27^{\prime \prime}-44^{\circ} 38^{\prime} 32.22^{\prime \prime}$ & \multirow{3}{*}{ Depression } \\
\hline & 17 & $97^{\circ} 27^{\prime} 30.92^{\prime \prime}-97^{\circ} 27^{\prime} 32.32^{\prime \prime}$ & $44^{\circ} 38^{\prime} 30.77^{\prime \prime}-44^{\circ} 38^{\prime} 31.73^{\prime \prime}$ & \\
\hline & 18 & $97^{\circ} 27^{\prime} 24.29^{\prime \prime}-97^{\circ} 27^{\prime} 25.67^{\prime \prime}$ & $44^{\circ} 38^{\prime} 30.72^{\prime \prime}-44^{\circ} 38^{\prime} 31.69^{\prime \prime}$ & \\
\hline \multirow{5}{*}{ VII } & 19 & $97^{\circ} 24^{\prime} 54.35^{\prime \prime}-97^{\circ} 24^{\prime} 55.75^{\prime \prime}$ & $44^{\circ} 41^{\prime} 2.15^{\prime \prime}-44^{\circ} 41^{\prime} 3.13^{\prime \prime}$ & \multirow{5}{*}{$\begin{array}{l}\text { Fixed sand } \\
\text { dune }\end{array}$} \\
\hline & 20 & $97^{\circ} 24^{\prime} 49.01^{\prime \prime}-97^{\circ} 24^{\prime} 50.41^{\prime \prime}$ & $44^{\circ} 41^{\prime} 0.45^{\prime \prime}-44^{\circ} 41^{\prime} 1.40^{\prime \prime}$ & \\
\hline & 21 & $97^{\circ} 24^{\prime} 49.41^{\prime \prime}-97^{\circ} 24^{\prime} 50.79^{\prime \prime}$ & $44^{\circ} 41^{\prime} 3.45^{\prime \prime}-44^{\circ} 41^{\prime} 4.43^{\prime \prime}$ & \\
\hline & 22 & $97^{\circ} 24^{\prime} 42.23^{\prime \prime}-97^{\circ} 24^{\prime} 43.62^{\prime \prime}$ & $44^{\circ} 41^{\prime} 2.53^{\prime \prime}-44^{\circ} 41^{\prime} 3.49^{\prime \prime}$ & \\
\hline & 23 & $97^{\circ} 24^{\prime} 46.68^{\prime \prime}-97^{\circ} 24^{\prime} 48.07^{\prime \prime}$ & $44^{\circ} 40^{\prime} 57.14^{\prime \prime}-44^{\circ} 40^{\prime} 58.06^{\prime \prime}$ & \\
\hline \multirow{5}{*}{ VIII } & 24 & $97^{\circ} 20^{\prime} 26.05^{\prime \prime}-97^{\circ} 20^{\prime} 27.44^{\prime \prime}$ & $44^{\circ} 49^{\prime} 1.65^{\prime \prime}-44^{\circ} 49^{\prime 2} .62^{\prime \prime}$ & \multirow{5}{*}{ Oasis } \\
\hline & 25 & $97^{\circ} 20^{\prime} 27.03^{\prime \prime}-97^{\circ} 20^{\prime} 28.42^{\prime \prime}$ & $44^{\circ} 49^{\prime} 2.66^{\prime \prime}-44^{\circ} 49^{\prime} 3.62^{\prime \prime}$ & \\
\hline & 26 & $97^{\circ} 20^{\prime} 31.52^{\prime \prime}-97^{\circ} 20^{\prime} 32.91^{\prime \prime}$ & $44^{\circ} 49^{\prime} 1.58^{\prime \prime}-44^{\circ} 49^{\prime} 2.53^{\prime \prime}$ & \\
\hline & 27 & $97^{\circ} 20^{\prime} 30.33^{\prime \prime}-97^{\circ} 20^{\prime} 31.72^{\prime \prime}$ & $44^{\circ} 48^{\prime} 57.66^{\prime \prime}-44^{\circ} 48^{\prime} 58.62^{\prime \prime}$ & \\
\hline & 28 & $97^{\circ} 20^{\prime} 28.96^{\prime \prime}-97^{\circ} 20^{\prime} 30.35^{\prime \prime}$ & $44^{\circ} 48^{\prime} 57.48^{\prime \prime}-44^{\circ} 48^{\prime} 58.40^{\prime \prime}$ & \\
\hline
\end{tabular}

Table 1. Coordinates and landscape characteristics of the study sites.

The size of our sample plots was designed as $30 \times 30 \mathrm{~m}$. The coordinates of four corners and the centre of each plot with flagging marks were measured using a GPS device with a handheld sighting compass. Within each plot, the growth Height (H), Basal area (BA) and Canopy area (CA) of each of shrubs were measured using altimeter rods, diameter, tape measure, etc. The $\mathrm{CA}$ and $\mathrm{BA}$ were derived from canopy diameter in two perpendicular directions and diameter at breast height or basal circumference, respectively. Above-ground biomass was calculated using an allometric equation for Haloxylon ammodendron species from Buras et al., (2012). The carbon stock was calculated based on the carbon contents of Saxaul wood, i.e. $48.5 \%$, as measured by Buras et al. (2012). 15 models were developed using linear models was carried out using SPSS software.
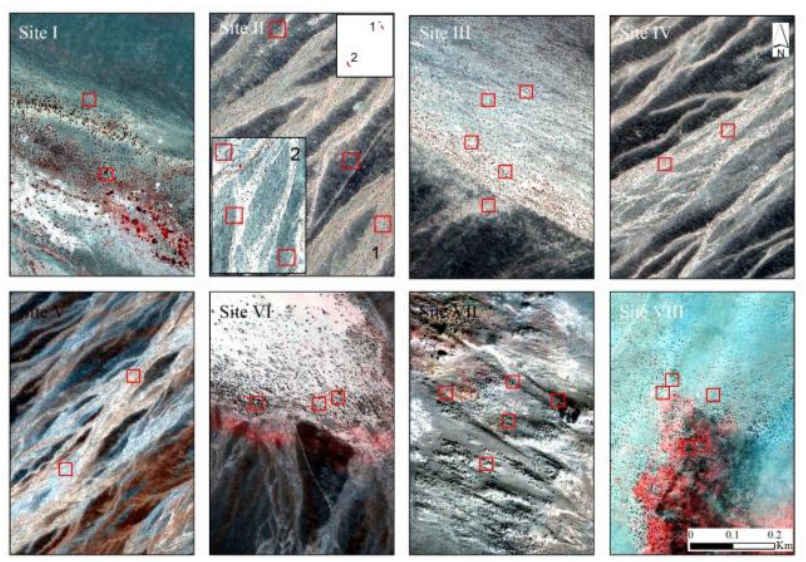

Figure 2. The false colour image of the satellite image, in which the red, green and blue colours are respectively displayed by NIR, Green and Blue bands of Pleiades-1 $(50 \mathrm{~cm})$. The images were acquired between July and September 2017. Shrub covers are shown from red to dark red colours. The red curve in the figure is the borderline of the plot area.

\subsection{Satellite data description and pre-processing}

The study was used high spatial resolution imagery of Pleiades1 (Multispectral) and both of active and passive data from Sentinel-1 (Synthetic Aperture Radar) and Sentinel-2 (Multispectral) imagery of the European Space Agency free downloaded from the agency's Copernicus Sentinels Scientific Data Hub. The Pleiades-1 data was included Ground Control Point for orthorectification with $50 \mathrm{~cm}$ panchromatric and $2 \mathrm{~m}$ spatial resolutions 4 spectral bands in the visible, near infrared. Sentinel-1 C-band $(5.405 \mathrm{GHz})$ images already multi-looked $(5 \times 1)$ Level-1 Ground Range Detected (GRD) processing level with high-resolution (a pixel size of $10 \mathrm{~m}$ ) including polarisations of $\mathrm{VH}$ (Vertical transmit - Horizontal receive) and VV (Vertical transmit - Vertical receive). The Sentinel-2 Level1C product already processed for radiometric and geometric corrections including orthorectification and spatial registration on a global reference system.

\begin{tabular}{|c|c|c|c|}
\hline Sensor & Relevant channel/index & & Definition \\
\hline Sentinel-1 & Polarisation/channel & $\begin{array}{l}\text { VH } \\
\text { VV }\end{array}$ & $\begin{array}{l}\text { VH channel }(\mathrm{dB}) \\
\text { VV channel }(\mathrm{dB})\end{array}$ \\
\hline Pleiades-1 & $\begin{array}{l}\text { Normalized Difference } \\
\text { Vegetation Index } \\
\text { Modified Soil Adjusted } \\
\text { Vegetation Index }\end{array}$ & $\begin{array}{l}\text { NDVI } \\
\text { MSAVI }\end{array}$ & $\begin{array}{l}(\mathrm{NIR}-\mathrm{RED}) /(\mathrm{NIR}-\mathrm{RED}) \\
(2 * \mathrm{NIR}+1-\operatorname{sqrt}((2 * \mathrm{NIR} \\
+1) 2-8 *(\mathrm{NIR}-\mathrm{R}))) / 2\end{array}$ \\
\hline Sentinel-2 & $\begin{array}{l}\text { Normalized Difference } \\
\text { Vegetation Index } \\
\text { Modified Soil Adjusted } \\
\text { Vegetation Index }\end{array}$ & $\begin{array}{l}\text { NDVI } \\
\text { MSAVI }\end{array}$ & $\begin{array}{l}(\text { Band } 8-\text { Band } 4) /(\text { Band } \\
8+\text { Band } 4) \\
((\text { Band } 8+1)-0.5 * \\
\text { Math.sqrt }\left((2 * \text { Band } 8-1)^{\wedge} 2\right. \\
+8 * \text { Band } 4))\end{array}$ \\
\hline
\end{tabular}

Table 2. Remote sensing data description and vegetation index. 
The data is an orthorectified, top-of-atmosphere reflectance with 13 spectral bands in the visible, near infrared and short-wave infrared regions and $10 \mathrm{~m}$ ( 4 bands), $20 \mathrm{~m}$ (6 bands) and $60 \mathrm{~m}$ (3 bands) spatial resolutions. Sentinel-1 SAR data was preprocessed consist of speckle filter, image calibration and terrain correction. The optical Pleiades-1 data was orthorectificated and pan-sharpened, Sentinel-2 image was atmospherically corrected and processed to Level-2A product to obtain bottom-ofatmosphere corrected reflectance image. The pre-process of the Sentinel-1 and Sentinel-2 data used SNAP free software (Sentinel's Application Platform) of the European Space Agency including SEN2COR atmospheric correction processor. All remote sensing data were used between July and September 2017.

\section{RESULTS AND DISCUSSION}

\subsection{Biomass and carbon stock estimation for field data}

The measured and calculated features as the growth Height $(\mathrm{H})$, Basal area (BA) and Canopy area (CA) for Haloxylon ammodendron from plots in eight different sites were statistically summarized in Table 3 together with estimated the results of each plot for total biomass and carbon stock of above and below ground were presented in Table 4.

The growing height in 32 plots is ranging from 20 to $460 \mathrm{~cm}$ with between 0.002 and $544.9 \mathrm{~cm} 2$ for basal area and between 526.5 and $166106.0 \mathrm{~cm} 2$ for canopy area, respectively (Table 3). Shrub density is very high in plot $4(n=135)$ and plot 5 $(\mathrm{n}=117)$ with low above-ground biomass $12 \mathrm{~kg}$ and $10.9 \mathrm{~kg}$. Most of plots are showing moderate shrub density widely varied from 1 to $51 \mathrm{~kg}$ for above-ground biomass with above and below ground carbon stock is ranging from 15.6 to $40.5 \mathrm{~kg}$ and from 1 to $16.7 \mathrm{~kg}$, respectively (Table 3). Highest levels are estimated in plot $19,51.9 \mathrm{~kg}$ for above-ground biomass with 25 $\mathrm{kg}$ for above-ground carbon stock. Some plots (plot 23, plot 24, plot 25, and plot 28; Table 3) particularly in sites VII and VIII showed very high biomass, indicating a significant big carbon stock occurring in sand dunes. From the comparison and simple analysis of field measured canopy and basal area with estimated above-ground biomass using allometric equation (Buras et al., (2012) for 1383 shrubs in 32 plots, we found that the field estimated above-ground biomass had the highest $\mathrm{R}^{2}(0.85)$ with canopy area and $\mathrm{R}^{2}(0.76)$, thus showed the good correlation (Fig. 3).
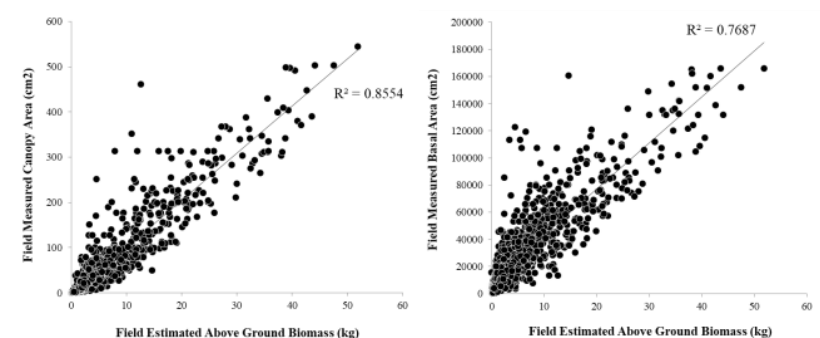

Figure 3. Scatter diagram showing the correspondence between measured canopy areas, basal area and estimated above-ground biomass using allometric equation (Buras et al., (2012) for 1383 shrubs in 32 plots.

\subsection{Relationship between field parameters and sensor signatures}

Fig. 5, Fig. 6 present the values of the NDVI, MSAVI, VV and $\mathrm{VH}$ in relation to the above-ground biomass, basal area and growing height of each plot. Band combination of NDVI and
MSAVI values have well correlations with above-ground biomass. Bands in VV and VH had good correlations with the basal area and growing height of each plot. Fig. 4 present the MSAVI map as shown vegetation cover of field study sites. The images were acquired between July and September 2017.

Backscatter $(\mathrm{dB})$ values of the vegetated area and non-vegetated were comparable, -27.86 and -17.36 in $\mathrm{VH}$ polarisation and -22.72 and -10.61 in VV polarisation, respectively. Nonvegetated areas under pond, salt pond and sand had lower backscatter value $(\mathrm{dB})$ in $\mathrm{VH}$ polarisation.
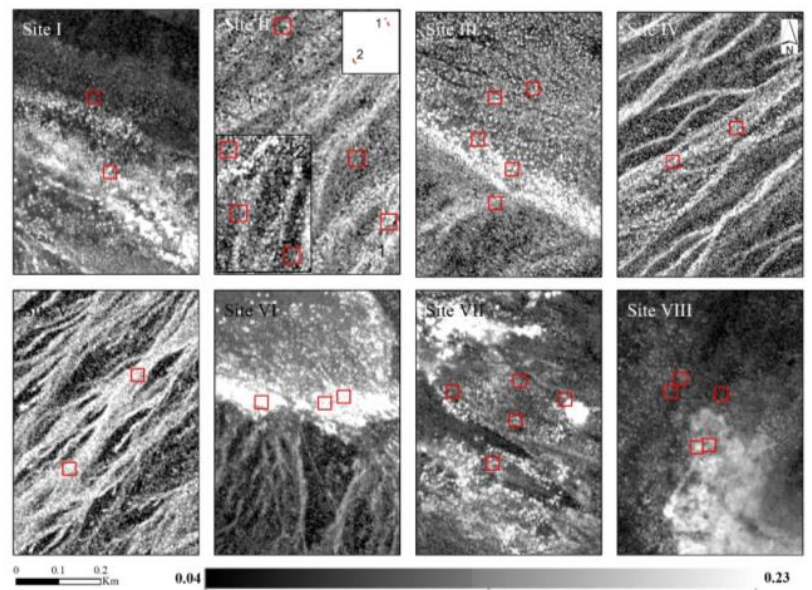

Figure 4. The MSAVI of Pleiades-1 (2 m) as shown vegetation cover of eight sites. The images were acquired between July and September 2017. Shrub covers are shown by white colours with the borderline of the plot area by the red curve in the figure.

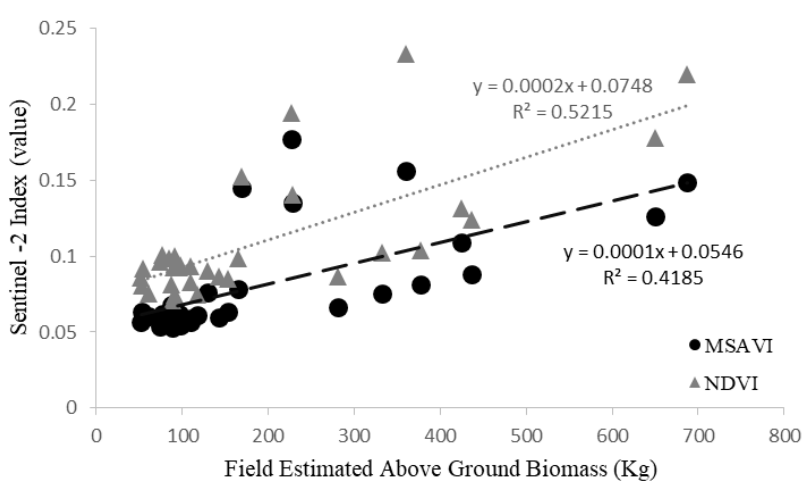

Figure 5. Relationships of field estimated above-ground biomass with Sentinel-2 derived vegetation indices as NDVI and MSAVI for each plot.

The significant correlation value (Fig. 5) obtained between NDVI, MSAVI and field estimated above-ground biomass using the images from Sentinel-2 ( $\mathrm{R}^{2} 0.52$ for NDVI, $\mathrm{R}^{2} 0.41$ for MSAVI), is comparable to those obtained between NDVI and biomass in dry forests of Argentina (Gasparri et al., 2010), between NDVI and crown closure in Venezuela (Feeley et al., 2005) and between Landsat TM bands and biomass in Brazil (Steininger, 2000). Fig. 6 displays a scatter diagram of the relationship between in field measured basal area and growing height and backscatter values of sentinel 1, the relationship of VH $\left(R^{2}=0.30\right)$ was weaker than that for $\mathrm{VV}\left(\mathrm{R}^{2}=0.41\right)$ for growing height. The relationship was found that the basal area is also a correlation with $\mathrm{VV}\left(\mathrm{R}^{2}=0.41\right)$, the correlation of $\mathrm{VH}$ $\left(\mathrm{R}^{2}=0.19\right)$ with the basal area was weak. 

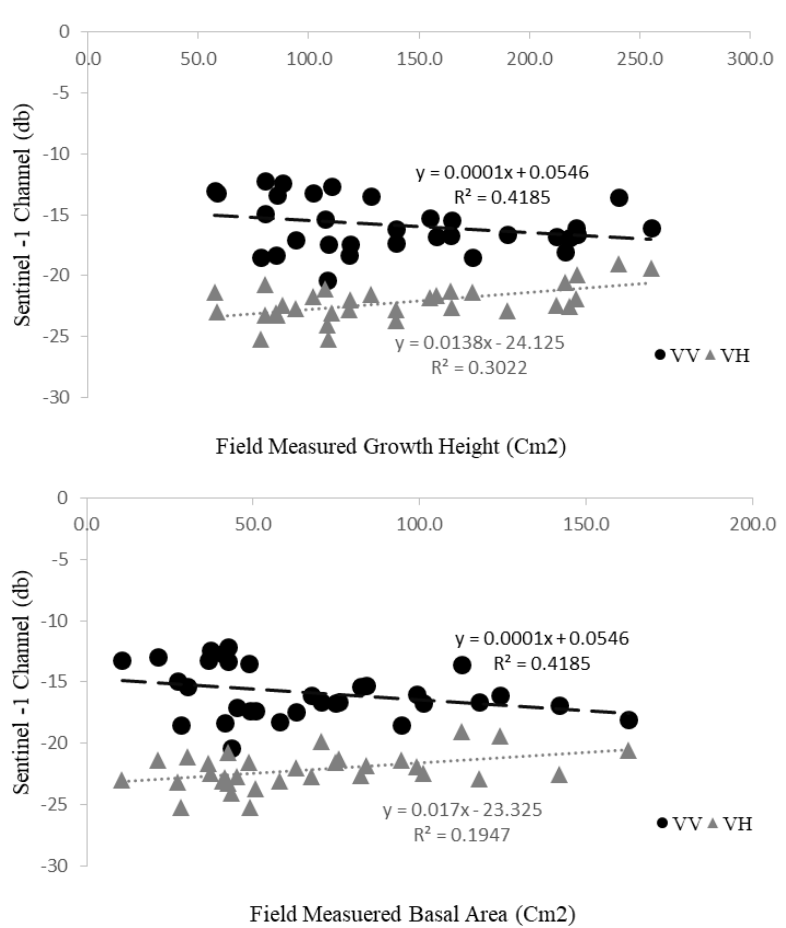

Figure 6. Relationships of basal area, growing height and Sentinel-1 SAR backscatter coefficient $(\sigma o, d B)$ in each plot.

\subsection{Estimation modelling for biomass and carbon stock using remote sensing data}

Compared to linear regression, the use of remote sensing method gave better biomass prediction from Sentinel-1 SAR and Sentinel-2-derived band combination and vegetation index, respectively. However, for Pleiades-1 and Sentinel-2 derived vegetation cover data (supervised classified vegetation cover area from Blues, Green, Red and NIR bands), linear regression gave better biomass prediction than band combination and vegetation index.
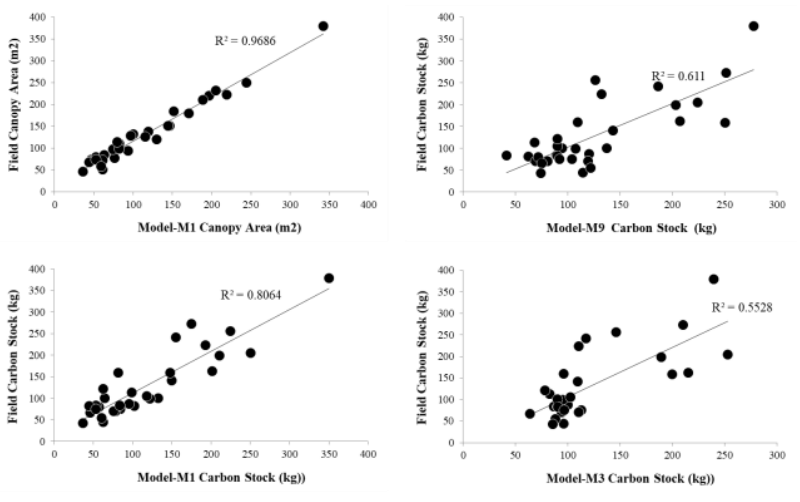

Figure 7. The relationship among field estimated and modelled above-ground biomass and carbon stock of top-three models for each plot size as 30x30m. For model details see Table 4 and Table 5 .

Table 4 shows the evaluation of biomass prediction from Pleiades-1 and Sentinel-2 derived vegetation cover area and Sentinel-1 SAR and Sentinel-2-derived band combination and vegetation index of observed and predicted values as well as the prediction error. Model-M1 was best modelled when a combination of vegetation coverage area was used as Pleiades-1 and Sentinel-2 derived vegetation cover data. For model-M9, the results were comparable to model-M1 but with lower $\mathrm{R}^{2}$ (Fig. 7). Finally, model-M1 was determined as the optimal model for estimation above-ground biomass using vegetation index to extract coverage. This model was expressed as AGB=$0.231+2.111 * \operatorname{Cov}$ and the detailed evaluation coefficients were shown in Table 4. Based on the selected optimal model as model-M1 linear regression analysis, the carbon stock of the study area was estimated and compared with field estimated carbon stock in Fig 8 and Table 5, the distribution was mapped as shown in Fig. 9. In this figure, the light grey marks area with no shrub, which is covered by bare land. The light green areas indicate the carbon stock lower than $20 \mathrm{~kg} / 100 \mathrm{~m}^{2}$ while the blue areas indicate a value higher than $40 \mathrm{~kg} / 100 \mathrm{~m}^{2}$.

\begin{tabular}{|c|c|c|c|c|c|}
\hline$\#$ & Models & $\mathrm{R}$ & $\mathrm{R}^{2}$ & $P$ value & $\begin{array}{l}\text { St. Error of the } \\
\text { Estimate (RMSE) }\end{array}$ \\
\hline M1 & $\mathrm{AGB}=-0.231+2.111 * \mathrm{Cov}$ & 0.851 & 0.723 & $<0.001$ & 3.933 \\
\hline M2 & $\mathrm{AGB}=-0.210+16.999 * \mathrm{Pndvi}$ & 0.747 & 0.557 & $<0.001$ & 0.488 \\
\hline M3 & $\mathrm{AGB}=-0.391+10.532 *$ Pmsavi & 0.749 & 0.561 & $<0.001$ & 0.486 \\
\hline M4 & $\mathrm{AGB}=-1.342+(-92.439 *$ Pndvi $)+67.626 *$ Pmsavi & 0.755 & 0.571 & $<0.001$ & 0.489 \\
\hline M5 & $\mathrm{AGB}=0.288+359.883 *$ Smsavi & 0.708 & 0.501 & $<0.001$ & 12.915 \\
\hline M6 & $\mathrm{AGB}=-3.762+302.413 *$ Sndvi & 0.706 & 0.499 & $<0.001$ & 12.194 \\
\hline M7 & $\mathrm{AGB}=-0.328+(-0.40 * \mathrm{VV})+359.577 *$ Smsavi & 0.708 & 0.501 & $<0.001$ & 13.136 \\
\hline M8 & $\mathrm{AGB}=118.334+1.103 * \mathrm{VV}+358.340 *$ Smsavi $+(-0.078 * \mathrm{Dem})$ & 0.735 & 0.54 & $<0.001$ & 12.834 \\
\hline M9 & $\mathrm{AGB}=223.07+0.185 * \mathrm{VV}+4.366 * \mathrm{VH}+(-0.09 * \mathrm{Dem})+258.772 *$ Smsavi & 0.782 & 0.611 & $<0.001$ & 12.010 \\
\hline M10 & $\mathrm{AGB}=-21.917+305.529 * \operatorname{Sndvi}+(-1.123 * \mathrm{VV})$ & 0.719 & 0.517 & $<0.001$ & 12.925 \\
\hline M11 & $\mathrm{AGB}=109.508+0.148 * \mathrm{VV}+307.265 *$ Sndvi $+(-0.087 * \mathrm{Dem})$ & 0.751 & 0.565 & $<0.001$ & 12.481 \\
\hline M12 & $\mathrm{AGB}=198.243+(-0.382 * \mathrm{VV})+3.585 * \mathrm{VH}+(-0.094 * \mathrm{Dem})+230.121 *$ Sndvi & 0.779 & 0.606 & $<0.001$ & 12.091 \\
\hline M13 & $\mathrm{AGB}=47.515+256.482 *$ Sndvi $+2.083 * \mathrm{VH}$ & 0.718 & 0.515 & $<0.001$ & 12.947 \\
\hline M14 & $\mathrm{AGB}=210.158+3.428 * \mathrm{VH}+232.977 *$ Sndvi $+(-0.102 *$ Dem $)$ & 0.778 & 0.605 & $<0.001$ & 11.893 \\
\hline M15 & $\mathrm{AGB}=77.339+292.505 *$ Smsavi $+3.226 * \mathrm{VH}$ & 0.741 & 0.549 & $<0.001$ & 12.484 \\
\hline
\end{tabular}


Table 4. Regression models to estimate above-ground biomass (AGB) using spectral data as Pleiades-1 both of active and passive data from Sentinel-1 and Sentinel-2 (between July and September 2017) as independent variable and field data (AGB) as a dependent variable. M1: AGB in $\mathrm{kg} / \mathrm{m}^{2}$; Cov is vegetation coverage are classified from remote sensing data. M2 - M4: AGB in $\mathrm{kg} / \mathrm{Pixel}$ (pixel area is $4 \mathrm{~m}^{2}$ ); Pndvi and Pmsavi are NDVI and MSAVIvalue of Pleiades-1. M5 - M15: AGB in $\mathrm{kg} / \mathrm{Pixel}$ (pixel area is $100 \mathrm{~m} 2$ ); Sndvi and Smsavi are NDVI and MSAVI values of Sentinel 2; $\mathrm{VV}$ and $\mathrm{VH}$ are Polarisation/channel of Sentinel 1; Dem is elevation extracted from Sentinel1.

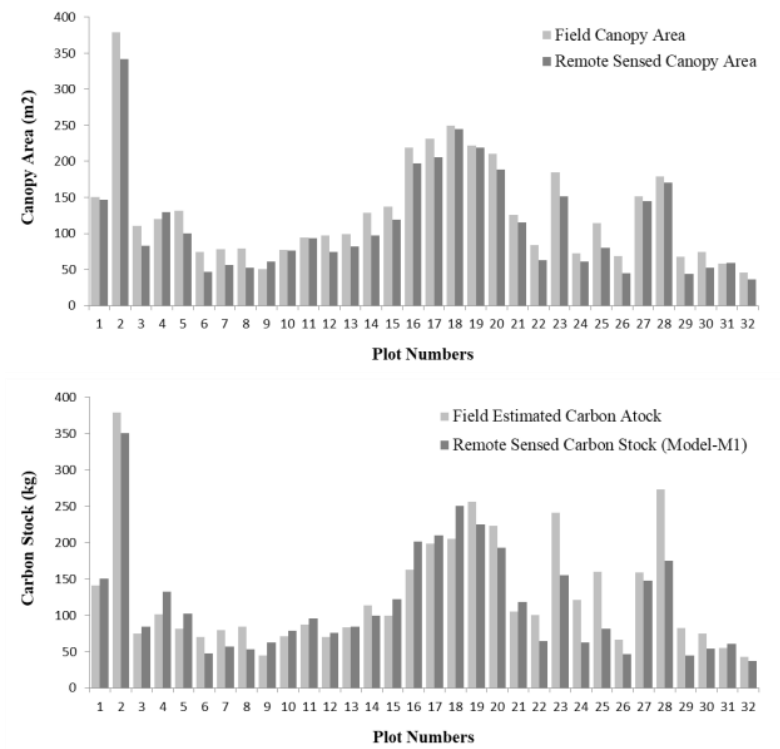

Figure 8. Field estimated carbon stock and remote sensed carbon stock (Model-M1) for each plot size is $30 \times 30 \mathrm{~m}$. For detailed values see Tables 4 and 5 .

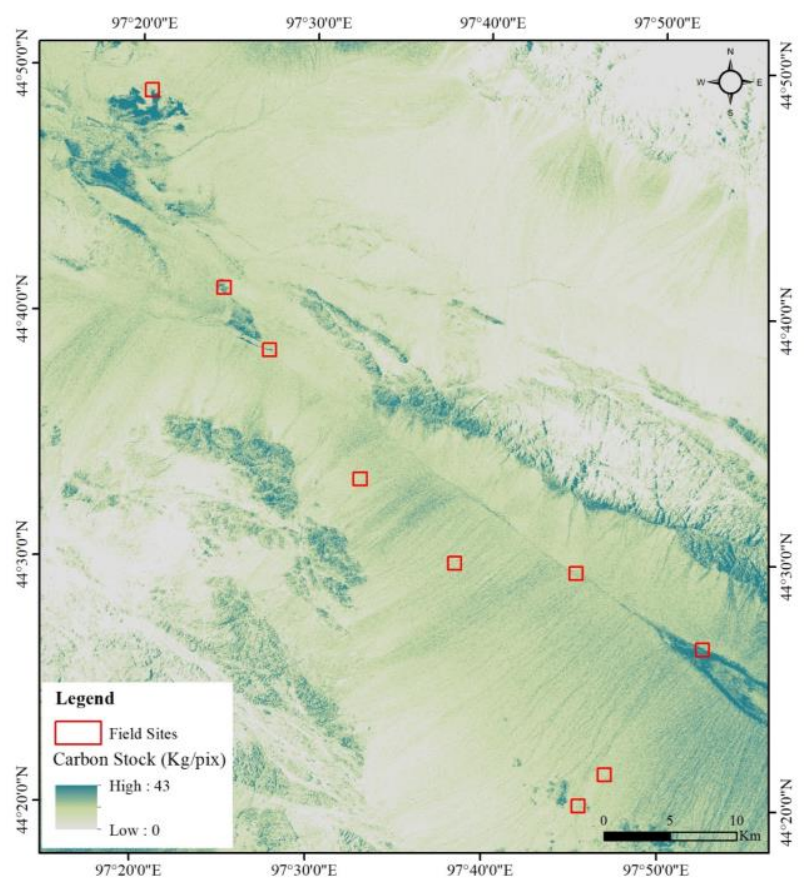

Figure 9. Shrubs carbon stock map in the western desert region of Mongolia. pix: Pixel area is $100 \mathrm{~m}^{2}$. Average carbon stock is $5.1 \mathrm{~kg} / \mathrm{pix}$ in this region.

\section{CONCLUSIONS}

Information on vegetation structure and particularly on biomass and carbon stock at a regional level is relevant for climate change research. In this context, remote sensing provides valuable data that can be related to field measurements for the development of environmental monitoring techniques.

Our results suggest that above-ground biomass and carbon stock in Haloxylon ammodendron of a temperate desert region can be estimated from Pleiades-1 and Sentinel-2 derived vegetation cover area and Sentinel-1 SAR and Sentinel-2-derived band combination and vegetation index with a linear equation. The differential vegetation phenology, which is strongly associated with groundwater availability, emerged as critical in determining the better image acquisition date to evaluate relationships between shrub structure and spectral data. The use of remote sensing data at the beginning of the fall season led to accurate above-ground biomass estimates. Although the NDVI and MSAVI have been widely used in describing the relationship between vegetation characteristics and spectral data, results vary depending on the ecosystem under study. In this work, NDVI and MSAVI appear as a good indicator of biomass mainly because it does not saturate in sparse shrubs and is more sensitive to canopy parameters.

\section{ACKNOWLEDGEMENTS (OPTIONAL)}

We thank the CADI fellowship program of Germany as well as the Michael Succow Foundation for funding and cooperation as well as our research team for assistance concerning. Special thanks to Nandinbayar Batsaikhan for valuable discussions and companionship throughout fieldwork.

\section{REFERENCES}

Buras, A.W., Zerbe, S., Noviskiy, Z., Muchitdinov, N., Shimshikov, B., Zverev, N., Schmidt, S., Wilmking, M. and Thevs, N., 2012. Allometric variability of Haloxylon species in Central Asia. Forest Ecology and Management, 274, 1-9, doi.org/10.1016/j.foreco.2012.02.023.

Chen, Y., Luo, G., Maisupova, B., Chen, X., Mukanov, B.M., Wu, M., Mambetov, B.T., Huang, J. and Li, C., 2016. Carbon budget from forest land use and management in Central Asia during 1961-2010. Agricultural and Forest Meteorology, 221, 131-141, doi.org/10.1016/j.agrformet.2016.02.011.

Eisfelder, C., Klein, I., Bekkuliyeva, A., Kuenzer, C., Buchroithner, M.F. and Dech, S., 2017. Above-ground biomass estimation based on NPP time-series - A novel approach for biomass estimation in semi-arid Kazakhstan. Ecological Indicators, 72, 13-22.

Feeley, K.J., Gillespie, T.W., Terborgh, J.W., 2005. The utility of spectral indices from Landsat ETMp for measuring the structure and composition of tropical dry forest. Biotropica 37 , 508-519.

Gasparri, N.I., Parmuchi, M.G., Bono, J., Karszenbaum, H. and Montenegro, C.L., 2010. Assessing multi-temporal Landsat 7 ETM+ images for estimating above-ground biomass in subtropical dry forests of Argentina. Journal of Arid Environments, 74(10), 1262-1270. 
Gunin, P.D., Vostokova, E.A., Dorofeyuk, N.I., Tarasov, P.E. and Black, C.C. eds., 2013. Vegetation dynamics of Mongolia Springer Science \& Business Media, 26.

Ji, C., Jia, Y., Gao, Z., Wei, H. and Li, X., 2017. Nonlinear spectral mixture effects for photosynthetic/non-photosynthetic vegetation cover estimates of typical desert vegetation in western China. PloS one, 12(12).

Jia, W., Liu, M., Yang, Y., He, H., Zhu, X., Yang, F., Yin, C. and Xiang, W., 2016. Estimation and uncertainty analyses of grassland biomass in Northern China: Comparison of multiple remote sensing data sources and modeling approaches. Ecological indicators, 60, 1031-1040.

Li, C., Zhang, C., Luo, G., Chen, X., Maisupova, B., Madaminov, A.A., Han, Q. and Djenbaev, B.M., 2015. Carbon stock and its responses to climate change in $\mathrm{C}$ entral A sia. Global change biology, 21(5), 1951-1967.

Ma, Q., Kuang, W., Liu, Z., Hu, F., Qian, J., Liu, B., Zhu, J., Cao, C., Wu, J., Li, X. and Zhou, Q., 2017. Spatial pattern of different component carbon in varied grasslands of northern China. Geoderma, 303, 27-36.

Shao, Z. and Zhang, L., 2016. Estimating forest aboveground biomass by combining optical and SAR data: A case study in Genhe, Inner Mongolia, China. Sensors, 16(6), 834.

Steininger, M.K., 2000. Satellite estimation of tropical secondary forest aboveground biomass: data from Brazil and Bolivia. International Journal of Remote Sensing 21, 11391157.

Thevs, N., Buras, A., Zerbe, S., Kühnel, E., Abdusalih, N. and Ovezberdiyeva, A., 2012. Structure and wood biomass of near- natural floodplain forests along the Central Asian rivers Tarim and Amu Darya. Forestry, 85(2), 193-202.

Thevs, N., Wucherer, W. and Buras, A., 2013. Spatial distribution and carbon stock of the Saxaul vegetation of the winter-cold deserts of Middle Asia. Journal of arid environments, 90, 29-35.

von Wehrden, H. and Wesche, K., 2007. Relationships between climate, productivity and vegetation in southern Mongolian drylands. Basic and applied dryland research, 1(2), 100.

von Wehrden, H., Hilbig, W. and Wesche, K., 2006. Plant communities of the Mongolian transaltay Gobi. Feddes Repertorium: Zeitschrift für botanische Taxomonie und Geobotanik, 117(7-8), 526-570.

Zhaglovskaya, A.A., Chlachula, J., Thevs, N., Myrzagaliyeva, A.B. and Aidossova, S.S., 2017. Natural Regeneration Potential of the Black Saxaul Shrubforests in Semi-Deserts of Central Asia-the Ili River Delta Area, SE Kazakhstan. Polish Journal of Ecology, 65(3), 352-368.

Zhang, C., Lu, D., Chen, X., Zhang, Y., Maisupova, B. and Tao, Y., 2016. The spatiotemporal patterns of vegetation coverage and biomass of the temperate deserts in Central Asia and their relationships with climate controls. Remote Sensing of Environment, 175, 271-281.

Revised January 2020 


\section{APPENDIX}

\begin{tabular}{|c|c|c|c|c|c|c|c|c|c|c|c|c|c|c|c|c|c|c|c|c|c|c|}
\hline \multirow[b]{2}{*}{ Sites } & \multirow[b]{2}{*}{ Plot No } & \multirow[b]{2}{*}{$\begin{array}{l}\text { Number } \\
\text { of Shrubs }\end{array}$} & \multicolumn{4}{|c|}{$\mathrm{H}(\mathrm{cm})$} & \multicolumn{4}{|c|}{$\mathrm{BA}(\mathrm{cm} 2)$} & \multicolumn{4}{|c|}{$\mathrm{CA}(\mathrm{cm} 2)$} & \multicolumn{4}{|c|}{ Above Ground Biomass (kg) } & \multicolumn{4}{|c|}{ Carbon Stock $(\mathrm{kg})$} \\
\hline & & & Min & Mean & $\operatorname{Max}$ & $\begin{array}{l}\text { Std. } \\
\text { Deviation } \\
\end{array}$ & Min & Mean & $\operatorname{Max}$ & $\begin{array}{l}\text { Std. } \\
\text { Deviation } \\
\end{array}$ & Min & Mean & $\operatorname{Max}$ & $\begin{array}{l}\text { Std. } \\
\text { Deviation } \\
\end{array}$ & Min & Mean & $\operatorname{Max}$ & $\begin{array}{l}\text { Std. } \\
\text { Deviation } \\
\end{array}$ & Min & Mean & $\operatorname{Max}$ & $\begin{array}{l}\text { Std. } \\
\text { Deviation } \\
\end{array}$ \\
\hline \multirow{7}{*}{ I } & Plot 1 & 40 & 35.0 & 118.9 & 235.0 & 46.9 & 1.1 & 62.8 & 298.5 & 74.7 & 3934.9 & 37626.6 & 98962.5 & 27772.6 & 0.4 & 7.3 & 27.3 & 7.1 & 0.2 & 3.5 & 13.3 & 3.5 \\
\hline & Plot 2 & 61 & 100.0 & 240.6 & 370.0 & 66.3 & 4.1 & 112.8 & 447.9 & 110.1 & 4415.6 & 62133.8 & 166106.0 & 39857.3 & 0.7 & 12.8 & 43.5 & 11.0 & 0.4 & 6.2 & 21.1 & 5.3 \\
\hline & Plot 3 & 39 & 56.0 & 107.6 & 200.0 & 35.4 & 0.9 & 30.1 & 150.7 & 37.4 & 5152.2 & 28384.1 & 73504.3 & 14170.9 & 0.3 & 4.0 & 13.2 & 3.2 & 0.2 & 1.9 & 6.4 & 1.6 \\
\hline & Plot 4 & 125 & 30.0 & 57.5 & 140.0 & 18.7 & 0.8 & 21.3 & 251.2 & 36.1 & 1319.6 & 9603.9 & 70650.0 & 10058.1 & 0.2 & 1.7 & 12.0 & 1.7 & 0.1 & 0.8 & 5.8 & 0.8 \\
\hline & Plot 5 & 117 & 20.0 & 58.5 & 140.0 & 29.0 & 0.02 & 10.6 & 107.5 & 22.7 & 706.5 & 11257.3 & 43354.0 & 11058.8 & 0.0 & 1.4 & 10.9 & 2.4 & 0.0 & 0.7 & 5.3 & 1.2 \\
\hline & Plot 6 & 47 & 30.0 & 88.0 & 175.0 & 41.4 & 0.4 & 37.1 & 314.0 & 64.7 & 1962.5 & 15787.9 & 67466.5 & 13193.3 & 0.2 & 3.1 & 21.9 & 4.1 & 0.1 & 1.5 & 10.6 & 2.0 \\
\hline & Plot 7 & 18 & 45.0 & 154.9 & 245.0 & 67.9 & 6.3 & 83.8 & 199.0 & 73.7 & 8654.6 & 43503.6 & 90506.5 & 25909.0 & 1.1 & 9.2 & 22.1 & 6.9 & 0.5 & 4.4 & 10.7 & 3.3 \\
\hline \multirow[t]{7}{*}{ II } & Plot 8 & 45 & 30.0 & 85.6 & 165.0 & 38.6 & 0.6 & 42.4 & 232.2 & 58.6 & 706.5 & 17663.1 & 51736.0 & 14294.8 & 0.1 & 3.8 & 18.0 & 4.5 & 0.1 & 1.9 & 8.7 & 2.2 \\
\hline & Plot 9 & 26 & 40.0 & 85.2 & 140.0 & 27.3 & 2.5 & 58.0 & 351.7 & 113.5 & 2826.0 & 19416.9 & 45216.0 & 13324.7 & 0.4 & 3.5 & 11.8 & 3.7 & 0.2 & 1.7 & 5.7 & 1.8 \\
\hline & Plot 10 & 27 & 45.0 & 109.0 & 257.0 & 52.5 & 0.6 & 49.1 & 201.0 & 76.1 & 3957.2 & 28701.7 & 116365.6 & 44598.1 & 0.3 & 5.0 & 25.3 & 7.2 & 0.1 & 2.4 & 12.3 & 3.5 \\
\hline & Plot 11 & 24 & 40.0 & 139.6 & 270.0 & 61.2 & 1.3 & 67.6 & 254.3 & 76.6 & 1962.5 & 39172.6 & 90746.0 & 24220.9 & 0.2 & 7.5 & 22.2 & 6.4 & 0.1 & 3.6 & 10.8 & 3.1 \\
\hline & Plot 12 & 30 & 50.0 & 94.2 & 217.0 & 35.2 & 1.8 & 45.0 & 251.7 & 70.0 & 11304.0 & 32426.3 & 89398.5 & 19424.4 & 1.0 & 4.8 & 16.4 & 4.3 & 0.5 & 2.3 & 8.0 & 2.1 \\
\hline & Plot 13 & 32 & 45.0 & 108.4 & 240.0 & 42.5 & 1.5 & 43.4 & 307.7 & 72.5 & 5024.0 & 30887.2 & 135146.5 & 26947.8 & 0.4 & 5.4 & 34.5 & 7.4 & 0.2 & 2.6 & 16.7 & 3.6 \\
\hline & Plot 14 & 72 & 28.0 & 78.4 & 165.0 & 31.3 & 0.2 & 28.4 & 132.7 & 33.9 & 1589.6 & 17801.3 & 53066.0 & 13813.4 & 0.1 & 3.2 & 13.0 & 3.3 & 0.0 & 1.6 & 6.3 & 1.6 \\
\hline \multirow[t]{3}{*}{ III } & Plot 15 & 60 & 35.0 & 80.1 & 160.0 & 30.8 & 0.02 & 27.3 & 188.6 & 41.2 & 2826.0 & 22910.8 & 85486.5 & 20491.7 & 0.0 & 3.4 & 17.7 & 4.0 & 0.0 & 1.7 & 8.6 & 1.9 \\
\hline & Plot 16 & 30 & 98.0 & 158.0 & 290.0 & 51.0 & 5.3 & 74.9 & 303.3 & 79.4 & 15662.5 & 73155.7 & 165046.5 & 65951.9 & 1.4 & 11.1 & 38.0 & 10.3 & 0.7 & 5.4 & 18.4 & 5.0 \\
\hline & Plot 17 & 40 & 119.0 & 164.3 & 270.0 & 50.4 & 17.0 & 75.9 & 371.0 & 102.8 & 22434.0 & 57849.4 & 162264.0 & 43980.0 & 3.1 & 10.2 & 41.7 & 11.0 & 1.5 & 5.0 & 20.2 & 5.4 \\
\hline \multirow[t]{5}{*}{ VI } & Plot 18 & 37 & 110.0 & 165.0 & 280.0 & 39.4 & 12.4 & 82.2 & 398.7 & 95.9 & 25216.0 & 67523.9 & 136250.0 & 32063.9 & 3.2 & 11.4 & 37.4 & 9.5 & 1.5 & 5.5 & 18.1 & 4.6 \\
\hline & Plot 19 & 36 & 65.0 & 218.2 & 320.0 & 70.2 & 2.8 & 142.0 & 544.9 & 158.0 & 6358.5 & 61734.7 & 166106.0 & 44971.0 & 0.6 & 14.7 & 51.9 & 14.3 & 0.3 & 7.1 & 25.2 & 6.9 \\
\hline & Plot 20 & 42 & 120.0 & 221.1 & 290.0 & 47.4 & 15.1 & 99.0 & 409.6 & 104.4 & 21371.6 & 50204.0 & 124178.5 & 25236.9 & 2.9 & 11.0 & 38.3 & 8.8 & 1.4 & 5.3 & 18.6 & 4.3 \\
\hline & Plot 21 & 35 & 50.0 & 139.4 & 240.0 & 44.5 & 2.3 & 50.5 & 173.1 & 39.3 & 5024.0 & 35886.9 & 107466.5 & 25791.8 & 1.2 & 6.2 & 14.6 & 4.2 & 0.6 & 3.0 & 7.1 & 2.0 \\
\hline & Plot 22 & 23 & 50.0 & 174.3 & 283.0 & 50.0 & 11.3 & 94.5 & 203.7 & 54.4 & 10885.9 & 36526.5 & 108474.0 & 24934.1 & 2.1 & 9.0 & 24.7 & 5.8 & 1.0 & 4.4 & 12.0 & 2.8 \\
\hline \multirow[t]{5}{*}{ VII } & Plot 23 & 33 & 105.0 & 216.1 & 400.0 & 66.0 & 5.5 & 162.9 & 498.7 & 165.6 & 2915.6 & 55996.2 & 115038.5 & 31015.7 & 1.0 & 15.1 & 40.5 & 13.0 & 0.5 & 7.3 & 19.7 & 6.3 \\
\hline & Plot 24 & 34 & 105.0 & 190.2 & 273.0 & 28.9 & 9.6 & 118.1 & 461.6 & 96.8 & 6358.5 & 21413.9 & 41526.5 & 8835.1 & 1.6 & 7.4 & 14.8 & 3.8 & 0.8 & 3.6 & 7.2 & 1.9 \\
\hline & Plot 25 & 40 & 120.0 & 212.2 & 310.0 & 45.4 & 3.1 & 101.0 & 342.0 & 82.5 & 11400.0 & 28515.7 & 74178.5 & 12534.4 & 0.9 & 8.2 & 26.6 & 5.2 & 0.4 & 4.0 & 12.9 & 2.5 \\
\hline & Plot 26 & 32 & 68.0 & 118.2 & 220.0 & 38.5 & 1.3 & 41.4 & 283.6 & 58.8 & 8987.5 & 21445.7 & 58962.5 & 13285.0 & 0.7 & 4.3 & 21.4 & 4.6 & 0.3 & 2.1 & 10.4 & 2.2 \\
\hline & Plot 27 & 49 & 160.0 & 221.8 & 450.0 & 63.2 & 8.0 & 70.3 & 314.0 & 84.2 & 8349.1 & 30826.1 & 85486.5 & 18878.5 & 1.3 & 6.7 & 20.9 & 5.3 & 0.6 & 3.2 & 10.1 & 2.6 \\
\hline \multirow[t]{2}{*}{ VIII } & Plot 28 & 57 & 150.0 & 255.2 & 460.0 & 69.5 & 3.8 & 124.3 & 368.2 & 96.4 & 2018.5 & 31391.1 & 76162.5 & 24112.5 & 0.5 & 9.9 & 27.9 & 8.0 & 0.2 & 4.8 & 13.5 & 3.9 \\
\hline & Plot 29 & 41 & 40.0 & 128.4 & 230.0 & 60.4 & 6.3 & 48.9 & 99.0 & 32.9 & 526.5 & 16598.8 & 63066.0 & 10447.7 & 0.2 & 4.1 & 8.2 & 2.4 & 0.1 & 2.0 & 4.0 & 1.2 \\
\hline \multirow[t]{2}{*}{$\mathrm{V}$} & Plot 30 & 43 & 45.0 & 102.1 & 160.0 & 35.2 & 1.3 & 36.4 & 99.3 & 30.6 & 3066.0 & 17184.0 & 35024.0 & 8012.8 & 0.3 & 3.6 & 8.6 & 2.4 & 0.1 & 1.7 & 4.2 & 1.2 \\
\hline & Plot 31 & 29 & 30.0 & 80.3 & 158.0 & 33.1 & 7.7 & 42.3 & 121.8 & 31.2 & 3957.2 & 19919.8 & 67850.0 & 18185.5 & 1.3 & 3.9 & 11.7 & 2.8 & 0.6 & 1.9 & 5.7 & 1.4 \\
\hline IV & Plot 32 & 19 & 60.0 & 110.4 & 165.0 & 39.0 & 1.6 & 40.9 & 93.0 & 27.3 & 3846.5 & 24289.4 & 67850.0 & 15380.4 & 0.5 & 4.7 & 9.8 & 2.9 & 0.2 & 2.3 & 4.7 & 1.4 \\
\hline
\end{tabular}

Table 3. Statistical summary of measured and calculated features as the growth Height (H), Basal area (BA), Canopy area (CA), Biomass (AGB)and Carbon stock (C) of above-ground for Haloxylon. The CA and BA were derived from canopy diameter in two perpendicular directions and diameter at breast height or basal circumference, respectively. The biomass was estimated using an allometric equation for Haloxylon species from Buras et al., (2012). Carbon contents for above-ground biomass are $48.5 \%$. 


\begin{tabular}{|c|c|c|c|c|c|c|c|c|c|c|}
\hline \multirow{2}{*}{ Plots } & \multicolumn{3}{|c|}{ Field Measured } & \multicolumn{3}{|c|}{ Model-M1 (Pleiades-1) } & \multicolumn{2}{|c|}{$\begin{array}{c}\text { Model-M3 (Pleiades-1 } \\
\text { MSAVI) }\end{array}$} & \multicolumn{2}{|c|}{$\begin{array}{c}\text { Model-M9 } \\
\text { (Sentinel 1,2) }\end{array}$} \\
\hline & $\mathrm{CA}\left(\mathrm{m}^{2}\right)$ & $\begin{array}{l}\text { AGB } \\
(\mathrm{kg})\end{array}$ & $\mathrm{C}(\mathrm{kg})$ & $\mathrm{CA}(\mathrm{m} 2)$ & $\begin{array}{l}\text { AGB } \\
(\mathrm{kg})\end{array}$ & $\mathrm{C}(\mathrm{kg})$ & AGB (kg) & $\mathrm{C}(\mathrm{kg})$ & AGB (kg) & $\mathrm{C}(\mathrm{kg})$ \\
\hline Plot 1 & 150.5 & 290.9 & 141.1 & 146.7 & 309.5 & 150.1 & 225.3 & 109.3 & 295.0 & 143.1 \\
\hline Plot 2 & 379.0 & 782.1 & 379.3 & 342.3 & 722.4 & 350.4 & 493.5 & 239.3 & 572.0 & 277.4 \\
\hline Plot 3 & 110.7 & 154.5 & 74.9 & 82.4 & 173.7 & 84.3 & 232.7 & 112.9 & 214.4 & 104.0 \\
\hline Plot 4 & 120.0 & 208.0 & 100.9 & 129.9 & 274.0 & 132.9 & 186.4 & 90.4 & 195.5 & 94.8 \\
\hline Plot 5 & 131.7 & 168.5 & 81.7 & 100.0 & 210.9 & 102.3 & 192.6 & 93.4 & 128.4 & 62.3 \\
\hline Plot 6 & 74.2 & 145.5 & 70.5 & 46.4 & 97.7 & 47.4 & 195.5 & 94.8 & 142.9 & 69.3 \\
\hline Plot 7 & 78.3 & 164.7 & 79.9 & 56.0 & 118.0 & 57.2 & 199.0 & 96.5 & 147.7 & 71.6 \\
\hline Plot 8 & 79.5 & 173.0 & 83.9 & 52.3 & 110.3 & 53.5 & 178.9 & 86.8 & 86.1 & 41.7 \\
\hline Plot 9 & 50.5 & 92.0 & 44.6 & 61.4 & 129.4 & 62.7 & 198.0 & 96.0 & 236.3 & 114.6 \\
\hline Plot 10 & 77.5 & 146.0 & 70.8 & 76.7 & 161.6 & 78.4 & 228.0 & 110.6 & 166.5 & 80.8 \\
\hline Plot 11 & 94.0 & 179.6 & 87.1 & 93.3 & 196.7 & 95.4 & 206.3 & 100.1 & 248.1 & 120.3 \\
\hline Plot 12 & 97.3 & 145.3 & 70.5 & 74.3 & 156.6 & 76.0 & 194.0 & 94.1 & 246.0 & 119.3 \\
\hline Plot 13 & 98.8 & 171.9 & 83.4 & 82.2 & 173.3 & 84.0 & 185.8 & 90.1 & 184.0 & 89.2 \\
\hline Plot 14 & 128.2 & 233.5 & 113.2 & 97.1 & 204.7 & 99.3 & 170.6 & 82.7 & 140.4 & 68.1 \\
\hline Plot 15 & 137.5 & 205.3 & 99.6 & 119.2 & 251.5 & 122.0 & 195.7 & 94.9 & 222.1 & 107.7 \\
\hline Plot 16 & 219.5 & 335.3 & 162.6 & 196.8 & 415.1 & 201.3 & 443.4 & 215.0 & 426.9 & 207.0 \\
\hline Plot 17 & 231.4 & 409.6 & 198.6 & 205.6 & 433.8 & 210.4 & 389.8 & 189.1 & 419.0 & 203.2 \\
\hline Plot 18 & 249.8 & 422.4 & 204.9 & 244.5 & 516.0 & 250.2 & 521.6 & 253.0 & 461.7 & 223.9 \\
\hline Plot 19 & 222.2 & 528.5 & 256.3 & 219.5 & 463.1 & 224.6 & 301.7 & 146.3 & 260.6 & 126.4 \\
\hline Plot 20 & 210.9 & 461.0 & 223.6 & 188.8 & 398.3 & 193.2 & 227.3 & 110.2 & 272.5 & 132.2 \\
\hline Plot 21 & 125.6 & 216.5 & 105.0 & 115.5 & 243.7 & 118.2 & 211.0 & 102.3 & 186.2 & 90.3 \\
\hline Plot 22 & 84.0 & 207.5 & 100.6 & 63.1 & 132.9 & 64.5 & 186.3 & 90.4 & 282.6 & 137.1 \\
\hline Plot 23 & 184.8 & 497.6 & 241.3 & 151.6 & 319.8 & 155.1 & 242.4 & 117.6 & 383.7 & 186.1 \\
\hline Plot 24 & 72.8 & 250.8 & 121.6 & 61.3 & 129.1 & 62.6 & 161.8 & 78.5 & 185.6 & 90.0 \\
\hline Plot 25 & 114.1 & 329.6 & 159.9 & 80.0 & 168.7 & 81.8 & 197.7 & 95.9 & 225.6 & 109.4 \\
\hline Plot 26 & 68.6 & 136.8 & 66.4 & 45.3 & 95.3 & 46.2 & 131.5 & 63.8 & 155.1 & 75.2 \\
\hline Plot 27 & 151.0 & 327.6 & 158.9 & 144.4 & 304.7 & 147.8 & 412.1 & 199.9 & 515.8 & 250.2 \\
\hline Plot 28 & 178.9 & 563.0 & 273.0 & 170.7 & 360.2 & 174.7 & 433.7 & 210.4 & 517.9 & 251.2 \\
\hline Plot 29 & 68.1 & 169.3 & 82.1 & 44.1 & 92.8 & 45.0 & 187.3 & 90.9 & 185.6 & 90.0 \\
\hline Plot 30 & 73.9 & 155.0 & 75.2 & 52.5 & 110.6 & 53.7 & 199.5 & 96.8 & 189.8 & 92.1 \\
\hline Plot 31 & 57.8 & 113.6 & 55.1 & 59.5 & 125.4 & 60.8 & 181.7 & 88.1 & 250.8 & 121.7 \\
\hline Plot 32 & 46.1 & 88.8 & 43.1 & 35.9 & 75.6 & 36.7 & 176.4 & 85.5 & 152.9 & 74.1 \\
\hline
\end{tabular}

